\title{
POST TRAUMATIC GROWTH PADA PENDERITA KANKER PAYUDARA
}

\author{
Ade Fitri Rahmah \& Erlina Listyanti Widuri \\ Fakultas Psikologi \\ Universitas Ahmad Dahlan \\ Jalan Kapas No 9 Yogyakarta \\ erlina_psiuad@yahoo.co.id.
}

\begin{abstract}
One of the deadly diseases for women is breast cancer. The wisdom defined in this study was post traumatic growth. Post traumatic growth is a positive changes experience arising from the struggle of the great crises of life. The purpose of this study was to determine the growth dynamics of post traumatic or post-traumatic growth toward positive life changes and want to understand further the factors that influence the formation of post traumatic growth in patients with breast cancer. The method used is based on qualitative research using phenomenology method. The analysis showed there were two factors that affecting the aspects of post traumatic growth in patients with breast cancer. External factors are the children and grandchildren as life expectation and as encouragement or motivation support of both parents to perform the treatment, so it eventually leads to the strengthening of internal factors. Internal factors include the factor of faith (spirituality), a strong desire to recover factors (optimism), resilience factors, and reframing factors. There are 4 (four) post traumatic growth arising from the struggle with breast cancer in the face of illness: an increase in spirituality, positive improvement in life, and the higher prosocial and better social relations.
\end{abstract}

Keywords: Breast Cancer, Post Traumatic Growth, Women.

\begin{abstract}
Abstrak
Salah satu penyakit yang berbahaya, bagi kaum wanita adalah kanker payudara yang berujung pada kematian. Tak sedikit penderita kanker payudara yang bertahan dengan kepasrahan dan keikhlasannya, sehingga
\end{abstract}


diperoleh hikmah yang terkandung di dalam penyakit. Hikmah yang dimaksud dalam penelitian ini adalah post traumatic growth yaitu pengalaman perubahan positif yang timbul dari perjuangan dari krisis kehidupan yang besar. Tujuan dari penelitian ini adalah untuk mengetahui dinamika post traumatic growth atau pertumbuhan pasca trauma menuju perubahan hidup yang positif dan ingin memahami lebih jauh lagi mengenai faktor-faktor yang mempengaruhi terbentuknya post traumatic growth pada penderita kanker payudara. Metode yang digunakan adalah metode penelitian kualitatif yang berlandaskan fenomenologi. Hasil analisis menunjukkan terdapat dua faktor yang mempengaruhi aspek post traumatic growth pada penderita kanker payudara. Faktor eksternal adalah anak dan cucu sebagai life expectation serta dorongan atau motivasi dari kedua orang tua secara terus menerus untuk melakukan pengobatan sehingga akhirnya memicu penguatan faktor internal. Faktor internal yang meliputi faktor keimanan (spritualitas), faktor keinginan kuat untuk sembuh (optimisme), faktor resiliensi, dan faktor reframing. Terdapat 4 (empat) post traumatic growth yang timbul dari perjuangan penderita kanker payudara dalam menghadapi penyakitnya: peningkatan spritualitas, positive improvement in life, prososial semakin tinggi, dan relasi sosial semakin baik.

Kata kunci: Penderita Kanker Payudara, Post Traumatic Growth, Wanita.

\section{Pendahuluan}

Salah satu jenis kanker yang paling ditakuti oleh para wanita adalah kanker payudara. Salah satu penyebabnya adalah karena penyakit ini tidak dapat disembuhkan jika ditemukan pada stadium lanjut. Seperti halnya kanker yang lain, kanker payudara bisa didiagnosis pada stadium yang berbeda-beda. Semakin dini kanker payudara ditemukan, kemungkinan sembuhnya semakin besar, namun jika ditemukannya pada stadium lanjut, maka harus dilakukan operasi pengangkatan payudara. Pada stadium lanjut kanker payudara bisa juga menyebar ke organ-organ lain seperti hati, tulang, paru-paru dan otak (Luwia, 2003). Semakin bertambah usia seorang wanita, semakin besar kemungkinan terserang kanker payudara. Kanker ini biasanya menyerang wanita muda atau dewasa. Wanita yang sering terkena kanker payudara adalah wanita yang berusia lebih dari 35 tahun dan yang tertua berumur 80-89 tahun. 
Word Health Organi ation (WHO) melaporkan bahwa di dunia ini setiap tahunnya ada 6,25 juta penderita kanker dan dalam dekade 20 terakhir ini ada 9 juta manusia meninggal karena kanker. Perlu dicatat bahwa 2/3 kejadian ini terjadi di negara yang sedang berkembang. Data dari Survei Kesehatan Rumah Tangga (SKRT) tahun 2001 menyebutkan bahwa kanker payudara menjadi penyebab kematian nomor lima di Indonesia. Kasus kematian penyakit kanker meningkat dari 3,4 persen pada tahun 1980 menjadi 6 persen pada tahun 2001. Jumlah penderita kanker payudara hingga saat ini diperkirakan menempati posisi kedua terbanyak setelah kanker leher rahim atau serviks.

Prevalensi kejadian tumor/kanker di Indonesia sendiri, menurut Riset Kesehatan Dasar (Riskesdas) tahun 2007, sebesar 4,3 persen per 1000 penduduk (Bambang, 2011). Di Indonesia data kanker payudara belum ada data yang pasti, tetapi berdasarkan data-data yang ada di rumah sakit pada umumnya kanker payudara menduduki tempat nomor dua setelah kanker serviks uteri. Data yang diperoleh dari instalansi radioterapi Rumah Sakit Kanker Darmais diketahui ada 10 besar jenis penyakit kanker berdasarkan letak tumor dari tahun 1995 sampai dengan tahun 2000 yakni kanker leher rahim 998 kasus, kanker payudara 897 kasus, nasofaring 578 kasus, paru-paru 401 kasus, thyroid 123 kasus, lidah 65 kasus, prostat 44 kasus, buli-buli 40 kasus.

Di Daerah Istimewa Yogyakarta (DIY), jumlah penderita kanker payudara belum dapat diketahui secara pasti. Data yang diperoleh hanya dari rumah sakit yang menangani pasien kanker payudara. Menurut data Dinas Kesehatan Propinsi DIY, di beberapa rumah sakit yang ada di DIY tahun 2009 ditemukan 451 kasus penderita kanker payudara (Dinkes, 2009). Tidak semua orang yang mengidap suatu penyakit menemukan hikmah dalam pengalaman sakit yang mereka rasa begitu halnya juga orang yang menderita penyakit kanker payudara. Hal ini juga mungkin bahwa post traumatic growth atau pertumbuhan pasca-trauma yang bermanfaat dalam beberapa konteks. Pada saat ini penderita kanker mungkin mengalami perubahan hidup yang positif setelah terdiagnosis mengidap penyakit kanker. Sekitar setengah dari orangorang keluar dari krisis kehidupan yang parah, kepekaan perasaan lebih meningkat daripada sebelumnya. Sedangkan pertumbuhan pasca trauma didefinisikan sebagai pengalaman perubahan positif yang signifikan timbul dari perjuangan dari krisis kehidupan yang besar.

Saat ini sebagian besar studi pada pertumbuhan pasca-trauma dilakukan terhadap pasien kanker di negara maju. Karena nilai-nilai, keyakinan dan pengalaman berbeda antara orang-orang dari berbagai negara, budaya dan asal-usul etnis, 
penelitian itu bertujuan menemukan jika penderita kanker yang tinggal di Malaysia, Indonesia dan Singapura berbagi perspektif yang sama seperti yang ada di negaranegara Barat. Hasil penelitian menunjukkan adanya pengalaman atau ekspresi perubahan hidup yang positif sebagai hasil dari menghadapi krisis kehidupan seperti kanker, dengan istilah-istilah seperti: mencari keuntungan, pertumbuhan pasca-trauma, ketahanan, berkembang, ilusi positif dan adaptasi kognitif. Sedangkan pertumbuhan pasca trauma lebih mengisyaratkan sesuatu yang akan diperoleh atau tingkat yang lebih tinggi untuk mencapai kualitas kehidupan psikososial. Ketika individu didiagnosis menderita penyakit yang mengancam hidupnya, individu sering memikirkan kembali makna dan tujuan hidup mereka dan mempelajari kembali prioritas mereka. Kadangkadang situasi drastis memaksa kita untuk mengambil proses menyakitkan seperti reevaluasi dan perubahan. Proses ini dapat membuat individu menjadi lebih matang dan berkembang.

Perubahan positif yang terjadi sebagai hasil dari menghadapi trauma yang mengancam kehidupan disajikan dalam berbagai cara, seperti: penerimaan meningkatkan kerentanan seseorang, meningkatkan apresiasi terhadap eksistensi sendiri dan penghargaan yang lebih besar terhadap kehidupan, meningkatkan persepsi kompetensi dan kemandirian memberikan kontrol dan keamanan yang lebih besar, peningkatan kasih sayang dan empati terhadap orang lain, hubungan lebih dekat dengan orang lain, keyakinan agama atau spiritual kuat yang berarti lebih besar tentang kehidupan dan penderitaan, kematangan psikologis dan emosional yang lebih besar dan perolehan nilai baru dan prioritas hidup.

Pertumbuhan pasca trauma memang tidak mudah, kadang-kadang individu merasa sakit ketika mau bangkit. Perjalanan dimulai dengan kehancuran dan defisit melalui perjalanan yang panjang untuk penyembuhan. Dalam prosesnya, asumsi hancur harus dipulihkan, kepercayaan diri untuk tumbuh kembali, fisik, emosi dan spiritual harus dipupuk. Pertumbuhan ini bukan hanya pengalaman intelektual dan itulah yang akan menjadikan kuat sebagai agen perubahan (CACare, 2011).

Ada tiga fase reaksi emosional penderita kanker ketika mengetahui bahwa penyakit yang dideritanya sudah stadium lanjut. Fase pertama, penderita kanker akan merasakan shock mental ketika dirinya diberitahu tentang penyakitnya, yaitu kanker. Pada fase kedua, penderita kanker akan diliputi rasa takut dan depresi. Dan pada fase ketiga, akan muncul reaksi penolakan dan kemurungan, tidak yakin bahwa dirinya menderita kanker. Terkadang penderita kanker menjadi panik dan melakukan hal-hal yang tidak berarti dan sia-sia. Setelah fase ini berlalu, pada akhirnya penderita kanker akan sadar dan menerima kenyataan bahwa jalan hidupnya telah berubah. 
Sebagian penderita kanker telah berpikir dan merasa lebih realitis dan mempercayakan sepenuhnya kepada dokter untuk kelanjutan pengobatan (Hawari, 2004).

Menurut Tedeschi dan Calhoun (1998) pertumbuhan pasca trauma adalah pengalaman perubahan positif yang terjadi sebagai akibat dari perjuangan yang sangat menantang situasi kehidupan. Konsep pertumbuhan pasca trauma (PTG) sebagai pengalaman perubahan positif yang signifikan timbul dari perjuangan dari krisis kehidupan yang besar antara lain: apresiasi peningkatan hidup, pengaturan hidup dengan prioritas baru, rasa kekuatan pribadi meningkat dan spiritual berubah secara positif.

Para penulis berusaha untuk mengeksplorasi pengalaman orang-orang yang tidak hanya bangkit kembali dari trauma, tetapi menggunakannya sebagai batu loncatan untuk perkembangan individu lebih lanjut atau pertumbuhan, dan perkembangan perilaku sosial yang lebih manusiawi dan organisasi sosial. Pertumbuhan pasca trauma juga memiliki dampak yang lebih besar pada kehidupan masyarakat, dan melibatkan perubahan mendasar atau wawasan tentang kehidupan yang tidak hanya mekanisme koping yang lain. Oleh karena itu, pertumbuhan pasca trauma sebagai perubahan positif yang signifikan dalam kehidupan, yang mempengaruhi kognitif dan emosional pada individu. Signifikansi perubahan ini bisa begitu besar, bahwa pertumbuhan ini dapat benar-benar transformatif (Tedeschi dan Calhoun, 1995). Selain itu, pertumbuhan pasca trauma juga merupakan kebalikan dari gangguan stres pasca trauma.

Ada beberapa cara yang dilakukan individu dalam pertumbuhan pasca trauma yaitu dengan memanifestasikan dirinya, dan manifestasi ini mungkin tidak sama pada setiap individu. Jenis hasil pertumbuhan digambarkan sebagai perubahan dalam persepsi diri, perubahan dalam hubungan interpersonal, dan perubahan dalam filsafat hidup (Tedeschi dan Calhoun, 1995). Penting untuk mempertimbangkan manifestasi sosial pertumbuhan juga, karena tampak bahwa peristiwa traumatik dialami oleh individu dan kelompok dapat mempromosikan perubahan sosial yang mendalam. Korban trauma yang telah berhasil diatasi dari traumanya dan telah mengatasi tekanan psikologis, persepsi pertumbuhan pasca trauma seharusnya membendung dari satu komponen yang konstruktif dan pada kenyataannya itu cermin sebuah adaptasi positif untuk trauma. Sedangkan sisi konstruktif dapat dibawa sejalan dengan penyesuaian terhadap kesehatan dalam jangka panjang, sisi ilusi mungkin dalam pelayanan jangka pendek paliatif dengan ada hubungan dengan adaptasi jangka panjang. Anggapan ini akan menjelaskan bahwa studi cross-sectional biasanya tidak menemukan hubungan sistematis antara pertumbuhan dan penderitaan, sedangkan hasil dari studi 
longitudinal menunjukkan adanya sedikit hubungan negatif antara pertumbuhan dan penderitaan dari waktu ke waktu.

Tadeschi dan Calhoun (1996) menyatakan sebuah isu yang belum terselesaikan untuk studi kepribadian dan pertumbuhan pasca trauma adalah sejauh mana pertumbuhan tersebut merupakan hasil dari proses, strategis yang terbukti efektif atau hasil dari perubahan spontan yang muncul dalam persepsi diri. Perbedaan ini penting karena karakteristik kepribadian yang memfasilitasi secara efektif, pertumbuhan pribadi berorientasi mungkin berbeda dari yang memfasilitasi perubahan otomatis atau tidak disengaja. Isu lain yang belum terselesaikan, sama pentingnya tetapi dikaburkan dalam teori saat ini dan penelitian, adalah apakah pertumbuhan pasca trauma secara tiba-tiba atau bertahap. Perubahan bertahap juga mungkin memerlukan karakteristik kepribadian dan proses yang berbeda dari perubahan secara mendadak. Untuk benar-benar memahami bagaimana kepribadian terlibat dalam pertumbuhan pasca trauma, kita perlu lebih sepenuhnya mengembangkan proses yang menentukan pertumbuhan sebagai hasil yang sesuai.

Berdasarkan uraian di atas dapat disimpulkan bahwa post traumatic growth (pertumbuhan pasca trauma) adalah pengalaman perubahan positif yang signifikan pada individu setelah mengalami krisis keadaan yang mengancam kehidupannya. Hasil penelitian menunjukkan bahwa individu yang telah mengalami pertumbuhan pasca trauma mencakup beberapa hal sebagai berikut: penghargaan lebih besar terhadap kehidupan, perubahan prioritas, lebih hangat, lebih hubungan intim, kekuatan pribadi yang lebih besar, dan pengakuan dari kemungkinankemungkinan baru atau jalan untuk hidup seseorang dan perkembangan spiritual. Dua karakteristik kepribadian yang dapat mempengaruhi kemungkinan bahwa orang dapat menggunakan pikiran positif setelah peristiwa traumatis yang menimpa mereka termasuk menyerahkan anggapan dan keterbukaan untuk mengalami.

Selain itu, optimis mungkin lebih mampu untuk memusatkan perhatian dan sumber daya pada hal-hal yang paling penting, dan melepaskan diri dari masalah yang tak terkendali dan kemampuan untuk berduka serta secara bertahap menerima trauma juga bisa meningkatkan kemungkinan pertumbuhan (Wikipedia, ensiklopedia bebas, 2009). Tedeschi dan Calhoun (1996) menilai persepsi pertumbuhan pasca trauma berkaitan dengan lima aspek yaitu: (1) Berhubungan dengan orang lain, (2) Kemungkinan-kemungkinan baru atau prioritas hidup baru, (3) Pertumbuhan pribadi, (4) Perubahan spiritual, (5) Apresiasi kehidupan atau penghargaan hidup.

Berdasarkan uraian di atas dapat disimpulkan bahwa dua karakteristik kepribadian individu yang mengalami pertumbuhan pasca trauma adalah pertama, 
individu mampu menggunakan pikiran positif setelah peristiwa traumatis yang menimpa mereka. Kedua, individu yang optimis mampu untuk memusatkan perhatian dan sumber daya pada hal-hal yang paling penting, dan melepaskan diri dari masalah yang tak terkendali dan kemampuan untuk berduka serta secara bertahap menerima trauma juga bisa meningkatkan kemungkinan pertumbuhan. Sedangkan aspek-aspek pertumbuhan pasca trauma di antaranya adalah berhubungan dengan orang lain, kemungkinan-kemungkinan baru atau prioritas hidup baru, pertumbuhan pribadi, perubahan spiritual dan apresiasi kehidupan atau penghargaan hidup.

Sebuah studi dengan pasien kanker dari Malaysia, Indonesia dan Singapura menunjukkan bahwa seperti rekan-rekan mereka di Barat, sebagian besar pasien mengambil manfaat sebagai akibat dari kanker mereka. Pasien-pasien ini menghargai hidup mereka lebih baik di samping telah tumbuh secara spiritual. Pertumbuhan pribadi mereka telah membuat mereka menjadi individu yang lebih baik dan mereka menjadi lebih sadar akan kebutuhan untuk mengembangkan hubungan yang lebih baik dengan orang lain (CACare, 2011).

Berdasarkan latar belakang permasalahan yang dialami para penderita kanker payudara, penulis ingin menjawab pertanyaan: Bagaimana pertumbuhan pasca trauma menuju perubahan hidup yang positif pada penderita kanker payudara setelah terdiagnosa penyakit tersebut? Selanjutnya, penelitian ini juga hendak menjawab pertanyaan: faktor-faktor apa saja yang mempengaruhi terbentuknya pertumbuhan pasca trauma menuju perubahan hidup yang positif pada individu setelah terdiagnosa penyakit kanker payudara?

\section{Metode Penelitian}

Metode penelitian yang digunakan dalam penelitian ini adalah kualitatif dengan menggunakan paradigma fenomenologi. Menurut Moleong (2005), metode penelitian kualitatif dalam paradigma fenomenologi berusaha memahami arti (mencari makna) dari peristiwa dan kaitan-kaitannya dengan orang-orang biasa dalam situasi tertentu. Strategi penyelidikan phenomenology, adalah penelitian untuk menggambarkan, menyelidiki, menemukan serta memahami struktur esensi fenomena (gejala) berdasarkan pengalaman yang dialami oleh individu (Himam, 2005). Alasan penelitian ini menggunakan metode kualitatif karena penelitian ini bertujuan untuk mengungkapkan gejala secara holistic kontekstual melalui pengumpulan data dari latar alami dengan memanfaatkan diri penulis sebagai instrumen kunci. Penelitian kualitatif bersifat deskriptif dan cenderung menggunakan analisis dengan induktif. 
Proses dan makna (perspektif subyek) lebih ditonjolkan dalam penelitian ini. Penelitian kualitatif adalah metode penelitian yang bermaksud untuk memahami fenomena tentang apa yang dialami oleh subjek penelitian misalnya perilaku, persepsi, motivasi, tindakan, dan lain-lain, secara holistik dan dengan cara deskripsi dalam bentuk kata-kata dan bahasa, pada suatu konteks khusus yang alamiah dan dengan memanfaatkan berbagai metode alamiah (Moleong, 2006).

Penggunaan pendekatan kualitatif menurut penulis dapat menggali penjelasan mengenai faktor-fakor yang menyebabkan pertumbuhan pribadi atau perubahan hidup yang positif pada penderita kanker payudara secara lebih mendalam. Kebebasan penelitian kualitatif juga dapat mendorong penulis menemukan fakta baru yang belum pernah terungkap dalam penelitian sebelumnya. Analisis isi (content analysis) merupakan metode analisis yang digunakan dalam penelitian ini mendiskripsikan pertumbuhan pasca trauma atau perubahan hidup yang positif yang dialami penderita kanker payudara.

Pertimbangan dalam penetapan sampel ini adalah seseorang yang pernah menderita penyakit kanker payudara baik dari stadium awal maupun stadium akhir dan ada rasa trauma akan penyakit yang dideritanya sehingga mengacam kehidupannya. Penulis menggunakan teknik sampling ini karena dapat langsung mengarahkan penulis pada karakteristik informan penelitian secara lebih pasti, sehingga informasi yang dikumpulkan benar-benar relevan dengan tujuan awal penelitian. Informan dalam penelitian ini adalah dua orang wanita, dimana perbedaan usia kedua informan relatif jauh. Informan pertama berusia 52 tahun dan mengidap kanker payudara stadium IV. Informan kedua berusia 24 tahun, akan tetapi ketika mengidap kanker payudara informan masih berusia 17 tahun. Pemilihan kedua informan tersebut untuk mengungkapkan lebih dalam mengenai pertumbuhan pasca trauma atau perubahan hidup yang positif pada kedua informan serta untuk mengetahui faktorfaktor apa saja yang mempengaruhi terbentuknya pertumbuhan pasca trauma pada diri kedua informan.

Dalam proses pengambilan data, penulis harus memperhatikan beberapa hal yang menjadi etika dalam penelitian kualitatif. Pertama harus ada informed consent, yaitu persetujuan dari informan bahwa ia akan menjadi bagian dari penelitian. Kedua, prinsip kerahasiaan, yaitu penulis akan menjamin kerahasiaan identitas informan, kecuali informan tidak menuntut kerahasiaan identitas darinya. Ketiga harus ada prinsip no harm, yaitu prinsip bahwa penelitian yang dilakukan tidak membahayakan atau memungkinkan terjadinya bahaya terhadap informan.

Metode pengambilan data yang dilakukan adalah dengan metode wawancara 
dan observasi. Metode wawancara yang akan digunakan adalah wawancara semi terstruktur, yaitu jenis wawancara yang dalam pelaksanaannya ada guide, ada pedoman tetapi pertanyaannya ditanyakan secara semu, disesuaikan dengan kondisi (Moleong, 2005). Tujuan dari wawancara jenis ini adalah untuk menemukan permasalahan secara terbuka, pihak yang diajak wawancara diminta pendapat, dan ide-idenya. Dalam melakukan wawancara, penulis perlu mendengarkan secara teliti dan mencatat apa yang dikemukakan oleh informan. Hal ini dilakukan agar sifat pertanyaan tidak kaku atau ketat, serta memungkinkan penggalian materi yang relevan.

Metode observasi dilakukan bersamaan dengan wawancara mengingat kedua metode ini saling mendukung dalam mendapatkan data yang diinginkan. Teknik pengamatan memungkinkan melihat dan mengamati sendiri, kemudian mencatat perilaku dan kejadian sebagaimana yang terjadi pada keadaan yang sebenarnya. Observasi yang dilakukan oleh penulis adalah non partisipan, penulis hanya sebagai pengamat tanpa terlibat dalam kehidupan maupun kegiatan informan. Observasi dilakukan di luar proses wawancara dan juga selama wawancara berlangsung yang memungkinkan penulis memperoleh data yang sifatnya non verbal, antara lain: gerakan tubuh, mimik muka atau ekspresi wajah dan intonasi suara informan saat wawancara serta juga tentang bagaimana kondisi informan penelitian yang dalam hal ini adalah penderita kanker payudara. Sebelum proses wawancara dan observasi penulis melakukan persiapan terlebih dahulu, antara lain untuk wawancara penulis akan membuat guide (petunjuk) pertanyaan semi terstruktur berdasarkan pada teori mengenai post traumatic growth pada penderita kanker payudara. Jenis guide ini dipilih untuk menghindarkan agar pada saat proses wawancara tidak melenceng terlalu jauh dari fokus penelitian.

Ekspresi non verbal informan serta perasaan-perasaan informan yang muncul selama proses wawancara dicatat. Hal ini dilakukan untuk keperluan pengecekan data atau klarifikasi terhadap pernyataan-pernyataan yang terungkap selama proses wawancara berlangsung, data yang diperoleh dalam observasi ini akan digunakan sebagai data penunjang kemudian hasil wawancara akan ditulis dalam bentuk verbatim. Kemudian dilakukan reduksi data, reduksi data dilakukan dengan cara koding dan kategori, setelah itu dilakukan analisis, analisis yang dilakukan dengan menggunakan analisis isi agar diperoleh data yang akurat dan mendalam.

Menurut Poerwandari (2007) yang dengan analisis isi adalah analisis yang mengacu pada kata-kata, arti atau makna, gambar, simbol, ide-ide, atau tema-tema yang dikomunikasikan oleh teks. Setelah semua data baik observasi maupun wawancara telah dianalisis, penulis melakukan triangulasi data. Data yang ditemukan 
dibandingkan sehingga ditemukan kategori-kategori yang mewakili temuan dari metode tersebut. Langkah akhir yang dilakukan penulis adalah melakukan verifikasi dan penarikan kesimpulan.

Dalam penelitian ini, guna mendapatkan suatu bentuk kredibilitas penelitian, penulis akan menggunakan metode triangulasi. Triangulasi dalam pengujian kredibilitas ini diartikan sebagai pengecekan data dari berbagai sumber dengan berbagai cara, dan berbagai waktu (Sugiyono, 2010). Dalam penelitian kualitatif, data akan lebih diyakini kebenarannyajika dua sumber atau lebih menyatakan hal yang sama. Patton (Poerwandari, 2007), menyatakan bahwa triangulasi dapat dibedakan dalam triangulasi data, triangulasi peneliti, triangulasi teori dan triangulasi metode. Sedangkan dalam penelitian ini menggunakan triangulasi data dan triangulasi metode. Triangulasi data yaitu digunakannya variasi sumber-sumber data yang berbeda. Data dari berbagai sumber berbeda dapat digunakan untuk mengelaborasi dan memperkaya penelitian. Dalam penelitian ini membandingkan data keadaan dan perspektif informan penelitian dengan pandangan atau pendapat orang lain atau orang-orang terdekat informan disebut sebagai significant person untuk mengecek kembali apa yang dikatakan oleh informan penelitian. Sedangkan triangulasi metode yaitu dipakainya beberapa metode yang berbeda untuk meneliti suatu hal yang sama.

\section{Hasil dan Pembahasan}

Berdasarkan hasil wawancara dengan informan, penulis menyimpulkan bahwa terdapat dua faktor yang mempengaruhi aspek post traumatic growth pada kedua informan. Faktor tersebut dapat dibagi menjadi faktor internal dan faktor eksernal. Faktor eksternal yang mempengaruhi post traumatic growth pada kedua informan adalah anak dan cucu sebagai life expectation dan dorongan atau motivasi dari orang tua secara terus menerus untuk melakukan pengobatan sehingga akhirnya memicu penguatan faktor internal pada kedua informan.

Dalam bahasa psikologi, hikmah yang dimaksud dalam penelitian adalah post traumatic growth atau pertumbuhan pascatrauma (PTG). Secara teoritis, konsep pertumbuhan pasca trauma (PTG) didefinisikan sebagai pengalaman perubahan positif yang signifikan timbul dari perjuangan dari krisis kehidupan yang besar antara lain: apresiasi peningkatan hidup, pengaturan hidup dengan prioritas baru, rasa kekuatan pribadi meningkat dan spiritual berubah secara positif.

Berdasarkan wawancara peneliti dengan kedua informan, peneliti menyimpulkan setidaknya terdapat 4 (empat) pertumbuhan pasca trauma (post 
traumatic growth) yang signifikan timbul dari perjuangan informan dalam menghadapi penyakit kanker payudara ini, antara lain: peningkatan spritualitas, positive improvement in life, prososial semakin tinggi, dan relasi sosial semakin baik. Informan pertama, walaupun selalu dibayangi dengan kematian lantaran divonis dokter menderita kanker stadium empat dan umumnya paling lama akan mampu bertahan hingga dua tahun saja. Akan tetapi dalam menyikapi kondisi psikologis demikian, justru memperkuat ibadahnya, seperti memperbanyak doa dan shalat malam (tahajud), supaya lebih dekat dengan Sang Pencipta. Sebagai orang yang beriman, dan yakin semua apa yang dilakukan di dunia akan dipertanggungjawabkan, maka informan pertama memanfaatkan sisaa umurnya untuk lebih dekat kepada Maha Pencipta. Tak jauh berbeda dengan informan pertama, informan kedua pun mengakui bahwa aspek spritualitasnya semakin meningkat. Sebagai manusia yang beriman, informan kedua juga yakin dan percaya bahwa semua ini adalah ujian dan cobaan yang menghampiri hidupnya. Bahkan informan kedua tetap bersyukur dengan adanya penyakit ini dan menyerahkan segala ketentuan kepada-Nya. Ungkapan rasa syukur ini sebetulnya representasi dari sikap informan kedua yang "nrimo" atau tawakal dengan segala cobaan dan ujian yang melanda dirinya. Lebih jauh, faktor tawakal merupakan gambaran ketauhidan seseorang, karena segala sesuatu adalah datang dan kembali hanya kepada-Nya.

Penjelasan di atas semakin memperkuat teori Tedeschi dan Calhourn (1996) yang mengatakan bahwa persepsi pertumbuhan pasca trauma hampir selalu berkaitan dengan aspek spritual. Spiritualitas dalam konteks ini mengacu pada rasa bersyukur yang lebih besar kepada Sang Pencipta, peningkatan rasa komitmen seseorang kepada tradisi keagamaan, atau pemahaman yang lebih jelas dari keyakinan agama seseorang.

Positive improvement in life pada kedua informan juga semakin terlihat. Dalam menjalankan aktivitas kesehariannya, informan pertama sangat termotivasi dan bersemangat. Justru di tengah sakitnya itu, informan pertama semakin giat bekerja. Menurutnya, berkerja tidak membuatnya merasa sakit, tetapi malah menyenangkan. Informan pertama lebih merasa seolah-olah dia tidak mengidap penyakit kanker payudara, ketika dia bekerja. Positive improvement kedua yang terlihat pada informan pertama adalah variabel kejujuran. Variabel kejujuran sebenarnya berangkat dari fakor kerterbukaan yang selalu dilakukan oleh informan pertama. Siapa saja yang bertanya, atau bahkan yang menyinggung tentang penyakitnya, informan tak segan-segan menceritakan apa adanya mengenai penyakit yang ia derita. Informan pertama tidak hanya terbuka pada keluarganya saja tetapi juga kepada siapa saja, terutama di lingkungan sekitar tempat tinggalnya. Keterbukaan ini sebetulnya sangat 
dipengaruhi oleh kesungguhan informan pertama dalam menyiasati penyakit kanker ini, dia cenderung enggan untuk menutup-nutupi penyakit ini, karena hanya akan berdampak pada rasa sakit. Sebab kemampuan untuk mengekspresikan perasaan dan mengungkapkan informasi pribadi penting untuk ditampilkan berhubungan dengan cara-cara yang positif untuk berbagai indeks kesehatan mental dan fisik. Dengan penyakit kanker ini, positive improvement yang membekas pada informan kedua adalah peningkatan apresiasi terhadap eksistensi sendiri dan penghargaan yang lebih besar terhadap kehidupan, dan peningkatan persepsi kompetensi dan kemandirian memberikan kontrol dan keamanan yang lebih besar. Kehadiran penyakit kanker ini telah menyadarkannya bahwa yang namanya sehat memang tidak ternilai harganya, sehingga informan kedua lebih meningkatkan tingkat kepeduliannya dan lebih intens untuk memperhatikan kesehatannya dibanding sebelum terdiagnosis penyakit kanker payudara ini.

Post traumatic growth ketiga yang ditemukan peneliti pada kedua informan adalah perilaku prososial semakin tinggi. Pada informan pertama, di tengah ketidakpastian sisa-sisa umurnya, dia selalu berbuat baik kepada sesama, semakin pekajiwanya terhadap persoalan yang terjadi di sekitarnya untuk selalu mengulurkan tangan kepada yang membutuhkan, sekalipun dia sedang mengalami penderitaan fisik dan mental lantaran penyakit kanker yang menyerangnya. Menurut masyarakat sekitar tempat tinggal informan, informan seperti bukan orang yang sedang sakit, karena informan masih merasa mampu dan kuat mengurus dirinya sendiri. Terlihat sekali informan pertama begitu optimis dalam menata kehidupannya dengan amal dan kebajikan yang ia lakukan, dengan niatan mudah-mudahan bisa sedikit meringankan penyakit yang ia derita. Selain itu, kebaikan ini pun merupakan sarana (wasilah) untuk lebih dekat kepada Maha Pencipta dan disembuhkan dari segala penyakit yang menimpanya.

Pada aspek relasi sosial, informan pertama cenderung meningkat. Hal ini dapat terlihat dari relasi informan terhadap suami, mertua, anak-anak dan masyarakat sekitar tempat tinggalnya menjadi lebih dekat dan lebih sayang dari sebelum terdiagnosis kanker payudara. Begitu juga yang terlihat pada informan kedua, dia antusias untuk membantu orang lain kelak kalau sudah sembuh. Karena setidaknya informan kedua telah mempunyai modal pengalaman untuk membantu orang lain yang terdiagnosis penyakit kanker payudara, walaupun bentuknya masih berupa saran dan anjuran. Dengan demikian dapat disimpulkan prososial informan kedua semakin meningkat. Namun dalam kesehariannya, penyakit kanker ini cukup membuat dia resah dan gelisah, sehingga menimbulkan dampak tersendiri, terutama mempengaruhi sikapnya 
dalam bergaul dengan sesama. Hal ini disebabkan oleh faktor usia yang relatif muda, karena di sekitar lingkungannya, belum ada remaja seusianya telah atau sedang mengalami penyakit kanker payudara sebagaimana yang ia derita. Dengan kata lain, relasi sosial informan kedua kalau dibanding dengan sebelum terdiagnosis penyakit kanker menunjukkan penurunan.

Berdasarkan realita di atas dapat disimpulkan bahwa ketika individu didiagnosis menderita penyakit yang mengancam hidupnya, individu sering memikirkan kembali makna dan tujuan hidup mereka dan mempelajari kembali prioritas mereka. Kadangkadang situasi drastis memaksa mereka untuk mengambil proses menyakitkan seperti reevaluasi dan perubahan. Proses ini dapat membuat individu menjadi lebih matang dan berkembang. Dengan kata lain, penelitian ini mendukung hasil sebuah studi dengan pasien kanker dari Malaysia, Indonesia dan Singapura yang menunjukkan bahwa seperti rekan-rekan mereka di Barat, sebagian besar pasien mengambil manfaat sebagai akibat dari kanker mereka. Pasien-pasien ini menghargai hidup mereka lebih baik di samping telah tumbuh secara spiritual. Pertumbuhan pribadi mereka telah membuat mereka menjadi individu yang lebih baik dan mereka menjadi lebih sadar akan kebutuhan untuk mengembangkan hubungan yang lebih baik dengan orang lain (CA Care, 2011).

\section{Simpulan}

Terdapat dua faktor yang mempengaruhi aspek post traumatic growth pada kedua informan. Faktor tersebut dapat dibagi menjadi faktor internal dan faktor eksernal. Faktor eksternal yang mempengaruhi post traumatic growth pada kedua informan adalah anak dan cucu sebagai life expectation serta dorongan atau motivasi dari kedua orang tua secara terus menerus untuk melakukan pengobatan sehingga akhirnya memicu penguatan faktor internal pada kedua informan. Sedangkan faktor yang dominan dalam mempengaruhi pertumbuhan pasca trauma (post traumatic growth) adalah faktor internal yang meliputi faktor keimanan (spritualitas), faktor keinginan kuat untuk sembuh (optimisme), faktor resiliensi, dan faktor reframing.

Mengungkap dan mencari jawaban atas pertanyaan peneliti tentang bagaimana dinamika terbentuknya post traumatic growth pada penderita kanker payudara maka ditemukan ada beberapa hal yang mempengaruhinya. Berdasarkan pada pembahasan, dapat diketahui bahwa menyimpulkan setidaknya terdapat 4 (empat) pertumbuhan pasca trauma (post traumatic growth) yang signifikan timbul dari perjuangan informan dalam menghadapi penyakit kanker payudara ini, antara lain : 
peningkatan spritualitas, positive improvement in life, prososial semakin tinggi, dan relasi sosial semakin baik. Ketika individu didiagnosis menderita penyakit yang mengancam hidupnya, individu sering memikirkan kembali makna dan tujuan hidup mereka dan mempelajari kembali prioritas mereka. Kadangkala situasi drastis memaksa mereka untuk mengambil proses menyakitkan seperti reevaluasi dan perubahan. Proses ini dapat membuat individu menjadi lebih matang dan berkembang.

\section{Daftar Pustaka}

Bambang. (2011). Kejadian Kanker Payudara Masih Tertinggi.http:// www.antaranews.com/berita/1265254914/kejadian-kanker-payudaramasih-tertinggi. 16 Maret 2011.

CA Care, (2011). Post-traumatik Pertumbuhan Kanker: Perspektif Pasien IndoMalaysia.http://ejtcm.com/2011/03/12/post-traumaticgrowth-in cancerperspectives-of-indo-malaysian-patients/. 17 Maret 2011.

Dinkes. (2009). Riset Kesehatan Daerah DIY. Yogyakarta : Dinkes.

Hawari, D. (2004). Kanker Payudara : Dimensi Psikoreligi. Jakarta : Penerbit Fakultas Kedokteran Universitas Indonesia.

Himam, F. (2005). Metodologi Penelitian Kualitatif. Workshop. Yogyakarta:

Lembaga Pendidikan Psikologi Industri Fakultas Psikologi Universitas Islam Indonesia.

Luwia. (2003). Problematika dan Perawatan Payudara. Jilid I. Depok : Kawan Pustaka.

Moleong, L.J. (2005). Metodologi Penelitian Kualitatif. Bandung : Tarsito.

Moleong, L. J. (2006). Metodologi Penelitian Kualitatif. Bandung : Remaja Rosdakarya.

Poerwandari, E. K. (2007). Pendekatan Kualitatif untuk Penelitian Perilaku Manusia. Jakarta: Lembaga Pengembangan Sarana

Sugiyono. (2010). Metode Penelitian Pendidikan. Bandung : Alfabeta.

Tedeschi, R. G., \& Calhoun, L. G. (1995). Trauma And Transformation: Growing In The Aftermath Of Suffering. Thousand Oaks, CA: Sage.

Tedeschi, R. G., \& Calhoun, L. G. (1996). The post traumatic growth inventory: Measuring the positive legacy of trauma. Journal of Traumatic Stress, 9, 
455471.

Tedeschi, R.G., \& Calhoun, LG. (1998). Posttraumatic Growth: Positive Changes in the Aftermath of Crisis. Mahwah, NJ. Publication: Lawrence Erlbaum Associates.

Wikipedia.(2009).Posttraumaticgrowth.http://en.wikipedia.org/wiki/ Posttraumatic_growth\&rurl=translate.google.co.id\#History. 11 Maret 2011. 